\title{
The Effect of Reward, Punishment, Interpersonal Communication and Discipline: Economic Course for Social Students Context
}

\author{
Destri Yaldi ${ }^{1}$ \& Jumerli Ariati ${ }^{2}$ \\ ${ }^{1}$ Universitas Negeri Padang, Padang, Indonesia \\ ${ }^{2}$ UIN SUSKA RIAU, Pekanbaru, Indonesia \\ jumerliariati@gmail.com
}

\author{
ARTICLE HISTORY \\ Received : 2020-05-09 \\ Revised :2020-05-30 \\ Accepted : 2020-07-13
}

\section{KEYWORDS}

Reward

Punishment

Interpersonal Communication Discipline

\begin{abstract}
The purpose of this study was to determine the effect of Reward, Punishment, Interpersonal Communication and discipline to social student achievement in economic subject at senior high school Rumbai Pekanbaru. The population in this study as many as 744 students. The sampling technique used was Random Sampling thus obtained a sample of 261 student. The research instrument used in the form of a questionnaire. Analysis of the data in this study using Path Aalysis using program SPSS 16.00 for windows. The results of this study show reward significant and positive impact on the discipline, punishment significant and positive impact on the discipline, interpersonal communication significant and positive impact on the discipline, reward significant and positive impact on the student achievement, punishment significant and positive impact on the student achievement, interpersonal communication significant and positive impact on the student achievement, and discipline significant and positive impact on the student achievement.
\end{abstract}

\section{Introduction}

Studying process is leading the human who could develop and actualize all of themselves ability. It's obtained in the education environment both in family, school and society (Zeegers, 2004). Basically, studying activities aim to bring out of the positive changes in order to people could lead a maturity (Rahmi, 2005). That change is showing the positive effect that is a achievement be a core of studying process (Graves, 2011). A lot of previous research explains the student achievement. For example, Cassidy's research (2012) classifies the studying methodology of students, ages, gender, studying priority, and academic control as the affecting factor of student achievement.

The student achievement in Indonesia particularly at Pekanbaru City is still come under the level of student achievement. Based on data from that school, as many $42,3 \%$ social student in senior high public school Pekanbaru Kecamatan Rumbai, don't graduate in daily examinations and must have attended the remedial examinations. In studying process, the student achievement can be affected by a few factor. Davis (2006) explained that reward is the important factor in creating a motivation for children to learn and expert to do something new such as a new skill. Arnold (2014) explained that the punishment has a positive result to increase a student achievement.
Besides reward and punishment, Siburian (2013) explained that through a good interpersonal communication could affect a student achievement as well. Barbour (1974) explained that focus interpersonal communication is on an attitude and will which is expanding an available choice to interpersonal communication, that is including on cognitive and affective fields.

Students discipline is the important things in a studying (Jessop, 2016). Stanley (2014) explained that there's a discipline and then a student achievement will be increasing as well and the fact is a discipline affectivity will be supporting a student achievement. Luiselli (2016) taking to heart the student discipline then will be mending the moral character students, increasing social abilities, decreasing anti-social behaved and increasing academic competitions.

Based on the above theory, subsequently that research is making a reward, punishment, interpersonal communication, and discipline as the affecting factor of student achievement. On this research, a reward, punishment, communication interpersonal will be an exogenous variable while a discipline will be an intervening variable and a student achievement will be an endogenous variable. This following is a conceptual framework. 


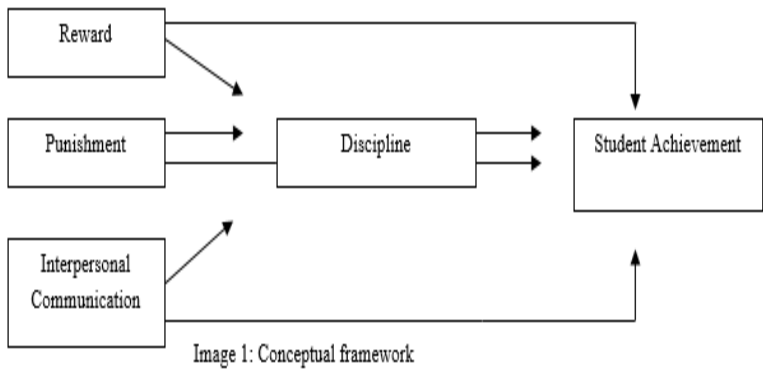

\section{METHOD}

The research is using quantitative method research and with descriptive type. This research sample is the social students in senior high public school Pekanbaru Kecamatan Rumbai. The research population is 774 students and the sample is 261 which is using the random sampling technique. This research instrument is using the questionnaire. The research data analysis is using Path Analysis with SPSS 16.00 for windows program.

\section{RESULT}

This research is explaining about the affecting factor of student achievement using a path analysis. The first path analysis (table 1) is explaining the affecting of a reward, punishment, communication, interpersonal for a discipline. The second path analysis (table 3) is explaining the affecting of a reward, punishment, communication, interpersonal for a student achievement.

\begin{tabular}{|c|c|c|c|c|c|}
\hline \multirow{3}{*}{ Model } & \multicolumn{2}{|c|}{$\begin{array}{c}\text { Unstandardized } \\
\text { Coefficients }\end{array}$} & \multirow{2}{*}{$\begin{array}{l}\text { Standardized } \\
\text { Coefficients } \\
\end{array}$} & \multirow{3}{*}{$\mathrm{t}$} & \multirow{3}{*}{ Sig. } \\
\hline & & Std. & & & \\
\hline & B & Error & Beta & & \\
\hline (Constant) & 27,740 & 5,665 & & 4,897 & 0,000 \\
\hline Reward & 0,147 & 0,060 & 0,135 & 2,443 & 0,015 \\
\hline Punishment & 0,550 & 0,071 & 0,437 & 7,756 & 0,000 \\
\hline \multicolumn{6}{|l|}{ Interpersonal } \\
\hline Communication & 0,123 & 0,060 & 0,111 & 2,043 & 0,042 \\
\hline
\end{tabular}

From the regression of model 1 on the coefficient table is known that the significant grade of third variable that is $X \neg 1=0,015, X 2=0,000$ and $X 3=$ 0,042 smaller than 0,05 . The result is giving a conclusion that the regression of model 1 that is $\mathrm{X} 1$, $\mathrm{X} 2$, and $\mathrm{X} 3$ taking significant effect for $\mathrm{X} 4$. To look the substantial contribution or the other variable path coefficients on the first path analysis could see on the table (2).

Table 2: Determination Coefficient, the effect of a reward $\left(\mathrm{X}_{\mathrm{I}}\right)$, punishment $\left(\mathrm{X}_{2}\right)$, comm interpersonal $\left(\mathrm{X}_{3}\right)$ for a discipline $\left(\mathrm{X}_{4}\right)$.

\begin{tabular}{ccccc} 
Model & $\mathrm{R}$ & R Square & Adjusted R Square & Std. Error of the Estimate \\
\hline 1 & 0,525 & 0,276 & 0,267 & 11,83464
\end{tabular}

The grade $\mathrm{R} 2$ on an above table is as big as 0,276 . The thing is showing up that contribution or effect X1, $\mathrm{X} 2$, and $\mathrm{X} 3$ for $\mathrm{X} 4$ which is as big as $27,6 \%$ meanwhile the leftover $72,4 \%$ is the contributions from the others variables which don't be input in this research. While for the grade to $\mathrm{Px} 4 \varepsilon$ will be explain with formula:

$$
P \times 4 \varepsilon=\sqrt{1-\mathrm{R} 2 \times 1 \times 2 \times 3}=\sqrt{0,724}=0,851
$$

$$
\begin{aligned}
& \text { The following is obtained the path of structure model } 1 \\
& \mathrm{X} 4=P_{\mathrm{x} 451} \mathrm{X} 1+P_{\mathrm{x} 4 \mathrm{x}_{2}} \mathrm{XX} 2+P_{\mathrm{x} 4 \mathrm{x}_{3} \mathrm{X} 3}+\mathrm{e} 1 \\
& \mathrm{X} 4=0,135 \mathrm{X}_{1}+0,427 \mathrm{X}_{2}+0,111 \mathrm{X}_{3}+0,85121
\end{aligned}
$$

The calculation results using SPSS version 16.00 program is obtained results from a substructure 2 and path coefficient of a reward, punishment, communication interpersonal for a student achievement which could see this following table 3 .

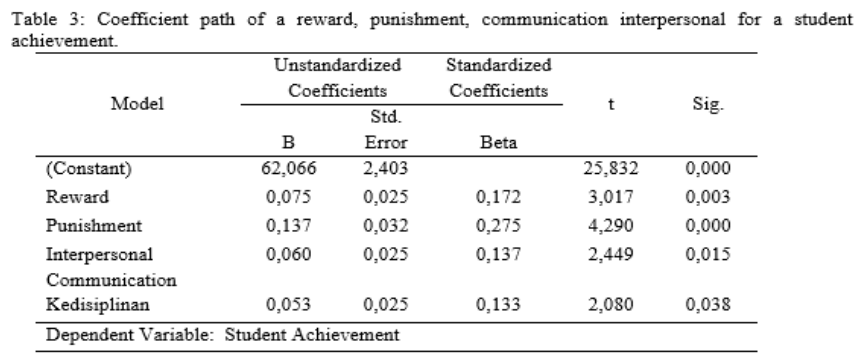

From the regression of model 2 on table 3 could be known the significant grade from fourth variable that is $\mathrm{X} \neg 1=0,003, \mathrm{X} 2=0,000, \mathrm{X} 3=0,015, \mathrm{X} 4=$ 0,038 smaller than 0,05 . The result is giving a conclusion that the regression of model 2 that is $\mathrm{X} 1$, $\mathrm{X} 2, \mathrm{X} 3$ and $\mathrm{X} 4$ taking a significant effect for $\mathrm{Y}$. To look the substantial contribution or the other variable path coefficients on the first path analysis could see on the table 4

Table 4: Determination Coefficient, the effect of a reviard $\left(X_{1}\right)$, punishment $\left(X_{2}\right)$, communication interpersonal $\left(X_{3}\right)$, discipline $\left(X_{4}\right)$ for a student achievement $(Y)$.

\begin{tabular}{ccccc}
\hline Model & $R$ & $R$ Square & Adjusted R Square & Std. Eror of the Estimate \\
\hline 2 & 0,493 & 0,243 & 0,231 & 4,80060 \\
\hline
\end{tabular}

The grade $\mathrm{R} 2$ on a table 26 is as big as 0,243 . The thing is showing up that contribution or effect $\mathrm{X} 1, \mathrm{X} 2$, $\mathrm{X} 3, \mathrm{X} 4$ for $\mathrm{Y}$ which is as big as $24,3 \%$ meanwhile the leftover $75,7 \%$ is the contributions from the others variables which don't be input in this research. While for the grade to Py\&2 will be explain with formula:

$$
\text { Pye2 }=\sqrt{1-R 2 \times 1 \times 2 \times 3 \times 4}=\sqrt{1-0,243}=\sqrt{0,757}=0,87
$$

The following is obtained the path of structure model 1 $\mathrm{Y}=P_{y x 1} X 1+P_{y \times 2} X 2+P_{y x 3} X 3+P_{y x} X 4+\varepsilon 2$

$\mathrm{Y}=0,172 \mathrm{X}_{1}+0,275 \mathrm{X}_{2}+0,137 \mathrm{X}_{3}+0,133 \mathrm{X}_{4}+0,87 \varepsilon_{2}$

Image 2: The structure of final path analysis 


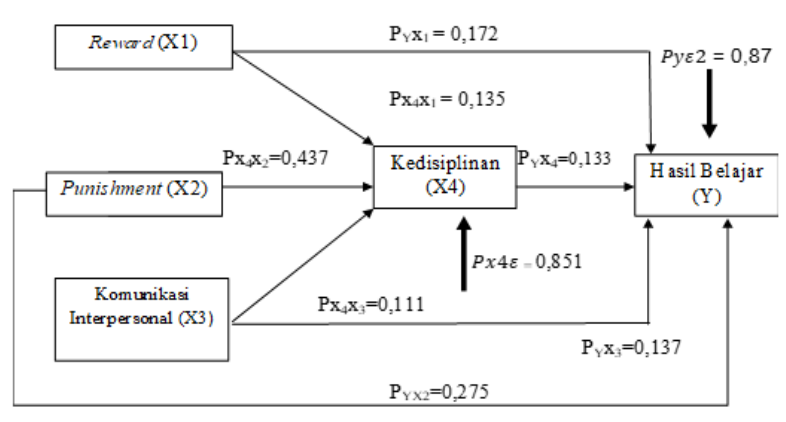

\section{Discussion}

\subsection{The Influence of Reward on Discipline}

Based on the results of the path analysis that has been done, the coefficient value of the direct effect of reward on discipline is $1.83 \%$ and the value of the coefficient of indirect effect of reward on learning outcomes through student discipline is $0.31 \%$. Hypothesis testing shows that reward has a positive and significant effect on discipline. This means that the intensity in giving rewards will determine the level of student discipline. This research proves that giving rewards to children will improve behavior in accordance with applicable rules, and make children to avoid themselves from actions that are not in accordance with the rules and behave in discipline.

This finding is in accordance with the opinion of Faidy (2014), Reward is an educational tool that is easy to implement and can please students, for that reward in an educational process requires its existence, because the role of reward in the teaching process can influence and direct student behavior. Choirun (2013) which explains that rewards are one of the elements in discipline.

\subsection{The Effect of Punishment}

Based on the results of the path analysis that has been done, the coefficient of direct influence on discipline is $19.09 \%$ and the coefficient of indirect effect on learning outcomes through student discipline is $1.71 \%$. Hypothesis testing shows that punishment has a positive and significant effect on discipline. This means that the intensity of the punishment will determine the level of discipline of students. This research proves that the provision of punishment in the field of education can improve behavior that is not in accordance with the norms that are believed to be by weakening behavior, and as an educational tool that can shape the discipline of children in complying with applicable rules.

This finding is in line with the opinion of Choirun (2013) who explains that punishment is one of the elements in the discipline of having a short-term goal is to stop wrong behavior. While the long-term goal is to teach and encourage children to stop their own wrong behavior. Punishment is an element of discipline that can be used to make children behave according to the standards set by their social groups.

\subsection{Interpersonal Communication Effect}

Based on the results of the path analysis that has been done, the coefficient of direct influence of interpersonal communication on discipline is $1.23 \%$. Hypothesis testing shows that interpersonal communication has a positive and significant effect on discipline. This means that good or bad interpersonal communication that is established will determine the level of student discipline. This research proves that interpersonal communication can change attitudes, opinions, or behavior both directly and indirectly (by using the media). In the principle of communication, when the communicant receives a message or information, it means that the communicant has got an influence from the communication process. Because basically, communication is a phenomenon, an experience. Each experience will give meaning to the situation of human life, including giving certain meanings to the possibility of changes in children's disciplinary attitudes.

This finding is in line with the opinion of Derin, et al : 2020; Marpaung et al: 2019; Haryono : 2016) who explains that teachers must have effective communication skills in disciplining students. Through effective communication skills the teacher is able to accept all feelings, and encourage compliance and reciprocity from students. Hence, this kind of communication event is so called interpersonal communication (Sapitri, et al: 2019).

\subsection{The Effect of Reward}

Based on the results of the path analysis that has been done, the coefficient value of the direct effect of reward on learning outcomes is $2.95 \%$ and the coefficient value of the indirect effect of reward on learning outcomes through student discipline is $0.31 \%$. Hypothesis testing shows that reward has a positive and significant effect on learning outcomes. This means that the intensity in giving rewards will determine the level of student learning outcomes. This research proves that reward as an educational tool is able to encourage children to improve their learning outcomes and become even more active in their efforts to improve the achievements they have achieved.

This finding is in line with the opinion of Jones (2016) which explains that reward is given in the form of material or social symbols that can influence attitudes and motivation in achieving certain learning goals. In an educational context, rewards are usually material offerings or social symbols of recognition intended to influence behavior and motivation can include the desire to reach subject goals. 
Hamid (2006) added that rewards are given to children with the intention of appreciation and pride in the work and achievements of children, as well as with the intention that children do it continuously, increase their enthusiasm and motivation and interest in work and study. With a good encouragement in learning will show good results.

In addition, through rewards will affect student discipline which will indirectly improve student learning outcomes. Choirun (2013) which explains that rewards are one of the elements in discipline. Onderi and Odera (2012), added in their research entitled Discipline as a tool for effective school management. This research shows that by applying discipline to every stakeholder in the school will be able to improve moral education, regulate attitudes and behavior, and improve the learning process and learning outcomes.

\subsection{The Effect of Punishment}

Based on the results of the path analysis that has been done, the coefficient of direct influence on learning outcomes obtained is $7.45 \%$ and the coefficient of indirect effect of punishment on learning outcomes through student discipline is $1.71 \%$. Hypothesis testing shows that punishment has a positive and significant effect on learning outcomes. This means that the intensity of the punishment will determine the level of student learning outcomes. This research proves that punishment as an educational tool can encourage children to improve their learning outcomes and become even more active in their efforts to improve the achievements they have achieved.

This finding is in line with the opinion of Ghersoff (2017) who explains that punishment can maintain the behavior of children in the school environment, besides that punishment can also be used to influence student learning and achievement. Punishment was effective at maintaining appropriate student behavior, school punishment would be expected to predict better learning and achievement among students.

Punishment is an element of discipline that can be used to make children behave according to the standards set by their social groups. Through discipline, student learning outcomes will indirectly increase. Stanley (2014) which explains the existence of discipline, student academic performance will also increase and the fact that the effectiveness of the discipline will support the results of student learning achievement.

6. Effect of Interpersonal Communication on Social Studies student learning outcomes in economic subjects in the state senior high school Pekanbaru, Rumbai district
From the results of the study note that interpersonal communication has a significant effect on social studies student learning outcomes in economic subjects in the state senior high school Pekanbaru, Rumbai district. Based on the results of the path analysis that has been done, the coefficient of the direct influence of interpersonal communication on learning outcomes is $1.87 \%$ and the coefficient of the indirect effect of interpersonal communication on learning outcomes through student discipline is $0.21 \%$. Hypothesis testing shows that interpersonal communication has a positive and significant effect on learning outcomes. This means that good or bad interpersonal communication that is established will determine the level of student learning outcomes.

This finding is in line with the opinion of Muflicah (2016) which explains that effective interpersonal communication in learning is a process of transforming messages in the form of science and technology from educators to students, where students are able to understand the purpose of the message in accordance with predetermined goals, thereby adding insight science and technology and lead to changes in behavior for the better.

Barbour (1974) explains that interpersonal communication focuses on attitudes and abilities which broadens the choices available for interpersonal communication, this includes the cognitive and affective domains. Nurochim $(2013,14)$ explains that there are three domains in learning outcomes namely, the cognitive domain, the affective domain, and the psychomotor.

Haryono (2016) which explains that teachers must have effective communication skills in disciplining students, through discipline the learning outcomes of students will increase. Onderi and Odera (2012), added in their research entitled Discipline as a tool for effective school management. This research shows that by applying discipline to every stakeholder in the school will be able to improve moral education, regulate attitudes and behavior, and improve the learning process and learning outcomes.

\subsection{The Effect of Discipline}

Based on the results of the path analysis that has been done, the coefficient of the direct influence of discipline on learning outcomes is $1.76 \%$. Hypothesis testing shows that discipline has a positive and significant effect on learning outcomes. This means that good or bad student discipline will determine the level of student learning outcomes. This research proves that the achievement of good learning outcomes is not only due to the presence of sufficient, good, and excellent intelligence, but also supported by strict and consistent discipline, individual discipline in learning, and also because of good behavior. 
This finding is in line with the opinion of Stanley (2014) which explains that with discipline the student's academic performance will also increase and the fact that the effectiveness of the discipline will support the results of student learning achievement. If school is effectively disciplined, the academic performance on the part of students and teachers will be highly rated (Stanley, 2014). The fact that effective discipline helps in the achievement of goals, expectation and responsibility in students (Dunham, in Stanley, 2014).

\section{CONCLUSION}

Based on the results of the processing and discussion of this study produces the following conclusions:

1) Reward has a significant influence on the discipline of social studies students in state high schools in Pekanbaru, Rumbai district. The form of the influence of the reward variable on discipline is positive. This means the better the reward given, the better the student's discipline.

2) Punishment has a significant influence on the discipline of social studies students in state high schools in Pekanbaru, Rumbai district. The form of the influence of the punishment variable on discipline is positive. This means that the better the punishment given, the better the student's discipline will be.

3) Interpersonal communication has a significant influence on the discipline of social studies students in state high schools in Pekanbaru, Rumbai district. The form of the influence of interpersonal communication variables on discipline is positive. This means that the more intense interpersonal communication is established, the better student discipline will be.

4) Reward has a significant influence on the learning outcomes of social studies students in state high schools in Pekanbaru, Rumbai district. The form of the influence of the reward variable on learning outcomes is positive. This means the better the reward given, the better the student learning outcomes. This study also shows that the direct contribution of rewards to learning outcomes is greater than the indirect effect through discipline.

5) Punishment has a significant influence on the learning outcomes of social studies students in state senior high schools in Pekanbaru, Rumbai district. The form of the influence of the punishment variable on learning outcomes is positive. This means that the better the punishment given, the better the student learning outcomes. This study also shows that the direct contribution of punishment to student learning outcomes is greater than the indirect effect through discipline.

6) Interpersonal communication has a significant influence on the learning outcomes of social studies students in state senior high schools in Pekanbaru, Rumbai district. The form of the influence of interpersonal communication variables on learning outcomes is positive. This means that the more intense personal communication is established, the better student learning outcomes. This study also shows that the direct contribution of interpersonal communication to student learning outcomes is greater than the indirect effect through discipline.

7) Kedisiplinan mempunyai pengaruh yang signifikan terhadap hasil belajar siswa IPS di sekolah menengah atas negeri Pekanbaru kecamatan Rumbai. Bentuk pengaruh variabel kedisiplinan terhadap hasil belajar adalah positif. Hal ini berarti semakin baik kedisiplinan siswa maka akan semakin baik pula hasil belajar siswa.

The student achievement is one of the important indicators to see a student studying activities in a certainly period of time. Whether successful the studying student or not could see from their student achievement. Hence, the substantial thing is for the teacher to pay attention the affecting factor of student achievement.

The path analysis result explained that a reward, punishment, communication interpersonal have a circumstantial effects for a student achievement through a discipline. That's mean giving a pedagogical reward and punishment and tying a good communication interpersonal will be pushing children to be discipline into a studying process. The children discipline into a studying process will be increasing a student achievement. a reward, punishment, communication interpersonal and discipline have a direct effect to form a student achievement.

\section{References}

Arnold, M. M., Chisholm, L. M., \& Prike, T. (2016). No pain no gain: The positive impact of punishment on the strategic regulation of accuracy. Memory, 24(2), 146-153.

Barbour, Alton. (1974). Interpersonal Communication: Teaching Strategy and Resource. United Stated of America: National Institute of Education, U. S. Department of Health, Education and Welfare.

Cassidy, Simon. (2012). Exploring individual differences as determining factors in student academic achievement in higher education. Studies in Higher Education. 37(7) 793-810

Davis, Winsler, \& Middleton (2006). Students' Perceptions of Rewards for Academic Performance by Parents and Teachers: Relations With Achievement and Motivation in College. 
The Journal of Genetic Psychology, 2006, 167(2), 211-220

Derin, T., Nursafira, M. S., Yudar, R. S., Gowasa, N. S., \& Hamuddin, B. (2020). Persuasive Communication: What Do Existing Literature Tells Us About Persuasive Communication Among Students?. Utamax: Journal of Ultimate Research and Trends in Education, 2(1), 12-18.

Grave, Barbarra. S. (2011). The effect of student time allocation on academic achievement. Education Economics 19( 3) 291-310

Jessop, Tansy. (2016). The influence of disciplinary assessment patterns on student learning: a comparative study. Studies in Higher Education, $41 \quad$ (4) 696-711. http://dx.doi.org/10.1080/03075079.2014.94317 0

Luiselli, James K. (2005). Whole-School Positive Behaviour Support: Effects on student discipline problems and academic performance. Educational Psychology. 25 (2-3) pp. 183-19.

Marpaung, A. P., Yanti, I., \& Marzuki, Y. (2019). Developing Students' Reading Comprehension Using STAD Strategy: A Classroom Action Research at SMA Negeri 7 Pekanbaru. REiLA: Journal of Research and Innovation in Language, l(1).

Rahimi, Mehrak. (2015). The role of teachers' classroom discipline in their teaching effectiveness and students' language learning motivation and achievement: A path method. Iranian Journal of Language Teaching Research 3(1), (Jan., 2015) 57-82

Sapitri, P. A., Chasanah, A., Putri, A. A., \& Paulima, J. (2019). Exploring Brown and Levinson's Politeness Strategies: An Explanation on the Nature of the Politeness Phenomenon. REiLA: Journal of Research and Innovation in Language, 1(3), 111-117.

Siburian Tiur Asi. (2013). The Effect Of Interpersonal Communication, Organizational Culture, Job Satisfaction, And Achievement Motivation To Organizational Commitment Of State High School Teacher In The District Humbang Hasundutan, North Sumatera, Indonesia. International Journal of Humanities and Social Science. Vol. 3 No. 12 (Special Issue - June 2013)

Stanley, Ehiane O. (2016). Discipline and Academic Performance (A Study of Selected Secondary School in Lagos, Nigeria). International Journal of Academic Research in Progressive Education and Development January. 2014, Vol. 3, No. 1
Wekke, I. S., Yandra, A., \& Hamuddin, B. (2017, December). Learning Strategy in Class Management: A Reflection from Manado Case. In IOP Conference Series: Earth and Environmental Science (Vol. 97, No. 1, p. 012053). IOP Publishing.

Zeegers, Peter. (2004). Student learning in higher education: a path analysis of academic achievement in science. Higher Education Research \& Development. Vol. 23, No. 1 